\title{
Research on the Marketing Strategy of New Energy Vehicles in SL Company
}

\author{
Jihua Zhang, Rong Wang \\ School of Management, Jinan University, Guangzhou, China \\ Email:mauritrous@163.com
}

How to cite this paper: Zhang, J.H. and Wang, R. (2019) Research on the Marketing Strategy of New Energy Vehicles in SL Company. American Journal of Industrial and Business Management, 9, 306-314. https://doi.org/10.4236/ajibm.2019.92020

Received: January 18, 2019

Accepted: February 18, 2019

Published: February 21, 2019

Copyright $\odot 2019$ by author(s) and Scientific Research Publishing Inc. This work is licensed under the Creative Commons Attribution International License (CC BY 4.0).

http://creativecommons.org/licenses/by/4.0/ (c) (i) Open Access

\begin{abstract}
New energy vehicle is a technological revolution in the automotive industry, which has changed the pattern of the original automotive industry to a certain extent. Nowadays, energy consumption and environmental pollution are becoming more and more serious, therefore new energy vehicles are becoming the trend of future industry development. Governments spare no efforts to promote new energy vehicles. In the case of its broad market prospects, the market gives new energy automotive enterprises a cold response. In addition to the heading companies, such as Tesla, small new energy automobile companies are still struggling to increase market share. Based on this, this paper mainly focuses on the marketing strategy of SL New Energy Automobile Company. Firstly, we overview the marketing theory, and introduce the SL new energy automobile company. Then we use PEST (Politics, Economy, Society, Technology) and SWOT (Strengths, Weaknesses, Opportunities, Threats) to analyze the macro and micro environment of SL company. Then we use STP (Segmentation, Targeting, Positioning) to decide the target market selection and positioning. Finally, we put forward the marketing strategy from the four aspects of SL company's product, price, place and promotion. Through this paper, we hope to have better marketing suggestions for enterprise managers, and hope to help the new energy automobile enterprise to promote market share.
\end{abstract}

\section{Keywords}

New Energy Vehicles, Marketing Strategy, Market Segmentation, Market Targeting, Market Positioning

\section{Introduction}

In spite of the bright future of new energy vehicles, the research on marketing 
strategies and models of new energy vehicle enterprises is very limited. The Institute of Transport Research at Waseda University has found that Japanese consumers are increasingly willing to use new energy vehicles [1]. According to a survey of the worldwide automobile consumers, the Rwe Group found that Indian consumers were the most willing to buy new energy vehicles, followed by Chinese consumers [2]. Chinese scholars have studied new energy vehicles lately. Xu and Xu (2010) pointed out that urban residents have higher willingness to buy new energy vehicles, but their actual purchasing behavior is less, mainly concerned about such problem as safety, after-sales service, parking lot and energy supplement [3]. Jin (2012) pointed out that compared with China, Japan's new energy vehicle market has gradually developed [4]. Xie (2013) proposed that the new energy automobile company should focus on the public transport system and rental services, and expand the market of the new energy automobile in the field of public transport through effective market strategy [5]. Sang and Zhang (2014) pointed out that although new energy automobile market received government support, the market reaction was not good [6]. So far, few studies have put forward effective marketing suggestions for actual enterprises. Therefore, this paper mainly explores the situation, market status and future development trend of SL New Energy Automobile Company, and analyses the internal and external environment and competitive advantages and disadvantages of SL Company, and then looks for the potential problems in marketing strategy of SL Company. Then, in view of SL Company's existing problems, this paper uses STP analysis method to subdivide the market, select the target market and reposition. Finally, based on $4 \mathrm{P}$ marketing theory, this paper puts forward corresponding marketing strategies from four aspects: product, price, channel and promotion to meet the needs of self-development and current competitive environment.

\section{Theory}

\subsection{Background}

Environmental and energy issues are major issues facing countries in the process of economic development [7] [8]. However, the high pollution and high energy consumption of traditional fuel vehicles have increasingly negative impact on people's survival and development, so the energy transformation of the automotive industry is imminent [9]. In this context, automobile companies around the world have introduced new energy vehicles, mainly hybrid and pure electric vehicles [10] [11]. This kind of automobile has less pollution, low energy consumption, intellectualization and humanization, which meets the needs of automobile transformation [12]. Governments have also issued policies to encourage the development and production of new energy vehicles, laying the foundation for the rapid development of new energy vehicles [13].

\subsection{PEST Model}

PEST is one of the most important models for macro environmental analysis. 
The PEST model analyses the macro-environment of industry and enterprise from four external environmental factors: politics, economy, society and technology. Specifically, P (Politics) refers to the political forces that have practical and potential impact on the organization's business activities, including government regulation and government subsidies; E (Economy) refers to the level of economic development and future economic trends of a country, including GDP and per capita income; S (Society) refers to the cultural traditions, values and customs of the society in which the organization is located. $\mathrm{T}$ (Technology) refers to inventions that cause revolutionary changes and new technologies related to enterprise production.

\subsection{SWOT Analysis}

SWOT analysis is one of the basic methods of marketing analysis, which is to analyze the competitive situation of enterprises from four aspects ( $, \mathrm{W}, \mathrm{O}, \mathrm{T})$. Firstly, the strengths ( $S$ ) of enterprises generally refer to the advantages that enterprises possess, including sufficient sources of funds, good corporate image and strong technical strength; secondly, the weaknesses (W) of enterprises generally refer to the shortcomings of enterprises, including insufficient funds, poor corporate reputation and backward technology; thirdly, the opportunities $(\mathrm{O})$ that enterprises possess generally refer to the enterprises in the process of development. Opportunities that can be exploited to promote their own development, including new products, new markets and new demands; Fourth, threats (T) faced by enterprises include potential new competitors, increased alternative products and changing consumer preferences.

The main purpose of SWOT analysis is to construct a set of efficient and concise strategy system, to list complex and difficult problems, and to formulate effective strategies and competitive strategies. Michael Porter put forward four alternative strategies: SO strategy, WO strategy, ST strategy and WT strategy.

\subsection{STP Strategy}

Philip Kotler systematically put forward STP strategy: S-Segmentation (market segmentation), T-Targeting (target market selection), P-Positioning (product positioning) [14]. Generally speaking, STP strategy can help enterprises to design products, services and image of the company on the basis of market segmentation, according to their own resource advantages, so that they can occupy a unique position in the minds of target customers.

\subsection{Marketing Combination}

J-McCarthy first proposed the 4P factors of marketing combination: Product, Price, Place, Promotion. In the process of marketing, it is the market, not the production, that decides what kind of products enterprises need to produce, what price strategies they should make, in what areas and why they should sell commercialized products and carry out relevant promotional activities. 


\section{Research Results of SL Company}

Firstly, the environment of new energy automobile industry is analyzed from four aspects: economy, politics, society and technology. Secondly, SWOT analysis of SL Company's internal environment is carried out to understand its strengths, weaknesses, opportunities and threats, and put forward corresponding strategies. Finally, the current marketing strategies of SL Company's new energy vehicles are analyzed, in order to understand its shortcomings in product strategy, placing strategy, pricing strategy and promotion strategy.

\subsection{Analysis of SL Company's External Environment}

China's economic growth rate has changed from the previous high-speed growth to the medium-speed growth. GDP grew by $10.6 \%$ year-on-year in 2010, and then slowed down gradually. GDP growth in $2011-2016$ was $9.5 \%, 7.9 \%, 7.8 \%$, $7.3 \%, 6.9 \%$ and $6.7 \%$ respectively. Since 2017 , the national economy has continued to develop steadily. In the first half of 2018, the gross domestic product reached $41,896.1$ billion yuan.

In terms of policy, in 2009, the financial department and the science and Technology Department jointly issued the document "Notice on Pilot Work of Energy-saving and New Energy Vehicle Demonstration and Promotion", and carried out the promotion of energy-saving and new energy vehicles in the taxi and bus fields of 13 cities.

Consumers' purchasing behavior will be affected by the social and cultural environment to a certain extent. In recent years, consumers have gradually formed the concept of low-carbon environmental protection, which has greatly promoted the development of new energy vehicles.

The key to the leaping development of new energy vehicles lies in the innovation. As far as China is concerned, the technology of new energy vehicles has made some progress, but the key technology is still in the hands of foreign advanced enterprises. Technical researchers in western developed countries account for $10 \%$ of the total workforce, while in China only $2.5 \%$. From the perspective of R\&D investment, for example, Volkswagen has more than $\$ 10$ billion. In addition, the $\mathrm{R} \& \mathrm{D}$ costs of Honda cars in Japan also account for $5.6 \%$ of sales revenue. However, most of the new energy automobile enterprises in China have less than $2 \% \mathrm{R} \& \mathrm{D}$ investment.

\subsection{Analysis of SL Company's Internal Environment}

1) Strengths. At present, SL company has built a huge sales network, which is a great advantage, and SL company attaches great importance to the maintenance of sales channels. With the acceleration of urbanization, the increase of per capita income and purchasing power, as well as the fact that the per capita car ownership in China is much lower than that in developed countries, the potential of the automobile market is enormous. In addition, SL's technical team has fully independent development experience and data accumulation of a variety of 
products, and has gradually formed its own technical development platform with its own characteristics and international level.

2) Weaknesses. There is still a certain gap between the development of new energy vehicles in China and the international advanced level. The supporting parts, charging stations, repairing shops and so on have not formed a certain scale. This situation has certain restrictions on the development of SL Company's new energy vehicles. In addition, compared with the world's advanced level, SL's new energy automobile core technology is still in a relatively backward position. Compared with traditional energy vehicles, the core parts of new energy vehicles are mainly batteries, motors and control systems. SL Company is still backward in these core technologies.

3) Opportunities. In recent years, more and more attention has been paid to energy shortage and environmental pollution. The use of traditional energy vehicles has caused serious environmental pollution. It has also damaged the health of residents to a certain extent, and brought a series of problems such as traffic congestion and noise pollution. The limitations of traditional energy vehicles make people gradually realize that clean energy should be developed to replace them. The consciousness of energy saving and environmental protection has gradually penetrated into the hearts of the people. The development of new energy vehicles conforms to the concept of green development and is a kind of green science and technology. It is gradually accepted by people for its advantages of energy saving, low carbon and environmental protection. The development of new energy vehicles has become a national development strategy, and there will be continuous policy and financial support.

4) Threats. The main threat comes from the competition of the same industry. As mentioned earlier, SL Company's new energy automobiles not only face the competition of foreign new energy automobile enterprises, but also face the competition of domestic new energy automobile enterprises. In product development, marketing channels, marketing strategies, automotive services and other aspects, the competition has reached a white-hot stage. In China's huge market, every enterprise in the industry wants to maximize its benefits, and has made every effort to solve this situation. For this situation, if we do not advance, we will go backwards. If SL can't make progress in these areas, it may be pushed out of the market by competitors very quickly.

\subsection{Improvement on Marketing Strategy of SL Company}

1) Product Strategy. Firstly, product quality improvement and new product design are carried out based on user experience. As an indispensable means of transportation, any unreasonable parts and design may lead to product quality problems and even endanger the personal safety of passengers and drivers. It will also have a fatal impact on the reputation of SL, a new brand. Therefore, SL Company should strictly control every part and design. On the premise of ensuring product quality, improving product quality based on user experience is 
also a good way to improve brand awareness, such as voice intelligent control, ergonomic seats and so on. Secondly, in the development of new energy products, SL Company should start with low-end and small electric vehicles, gradually extend to mid-grade pure electric vehicles, and create a product structure covering the middle and low-end market according to the different uses of the products, so as to fully meet the needs of target consumers.

2) Placing Strategy. SL Company should actively use e-commerce to broaden the channels of network sales. According to the latest data from China Internet Information Center, the scale of Internet users has exceeded 800 million, the penetration rate has reached $57.7 \%$, and the scale of mobile Internet users has reached 788 million. Internet has become an important channel for people to search and buy. Under this background, SL company should increase investment in business platform, increase the construction of its own official network, build a single online customer service section. At the same time, it should cooperate with the mainstream automobile vertical e-commerce platform and comprehensive e-commerce platform, and make full use of network technology for accurate advertising and App Design promotion

3) Pricing Strategy. Implement differentiated infiltration pricing strategy. Infiltration pricing is an enterprise that uses lower prices to rapidly increase sales and increase market share, so as to achieve the goal of quickly seizing the market. From the current situation of SL Company, its current goal should be to seize market share, profit growth as a secondary goal. At the same time, penetration pricing does not mean that enterprises should always focus on low prices. Simple low prices will cause consumers' doubts about the quality of products. Differential pricing should be carried out for target groups.

4) Promoting Strategy. SL Company can spread brand information by integrating various channels to enhance consumer brand awareness. In addition, SL can organize exhibitions to enable consumers to fully feel the SL's new energy vehicles, playing a better publicity role for the company's brand and products. Further, enterprises should actively assume social responsibilities. For example, by sponsoring and supporting public welfare activities, SL Company can establish a responsible corporate image, win the recognition of consumers, especially young consumers, and enhance brand image.

\section{Conclusion}

Through analysis, this paper puts forward some suggestions for SL Company's future marketing development. First of all, SL Company should focus on young people who are curious about automobiles and technology, creating products with a sense of technology, large space and price advantages. Secondly, SL Company should enrich the product structure, starting with low-end and small-sized electric vehicles, and gradually extend to mid-grade pure electric vehicles. SL Company should gradually create a product structure covering the mid-low-end market, increase small cars or compact cars, and develop SUV systems according 
to the different uses of products. Then, in order to expand consumer contact channels, the company should strengthen the layout of second and third-tier city outlets, form strategic alliances with industry giants, upstream and downstream industry chains, and use e-commerce to expand network sales channels. Finally, SL car should be located in the "60 thousand- 80 thousand" pricing range, and implement the "bare car sales + battery leasing" marketing model. Finally, SL should actively integrate all kinds of channels to spread brand information to build consumer brand awareness, and lay out the hot green sharing and Real Leasing business, so as to reduce the purchase resistance of target groups.

\section{Discussion}

\subsection{Implications for Enterprises}

With the concept of sustainable development being deeply rooted in the hearts of the people, the development of new energy vehicles has become an inevitable trend. All sectors of society are concerned about new energy. The government is also strongly supporting the development of the industry. However, as a new industry, the development of the market also leads to many problems. Therefore, this article through the analysis and suggestions of SL Company's new energy vehicle marketing strategy, on the one hand, is to implement the marketing theory to promote the development of new energy vehicles. On the other hand, taking SL Company as an example, it provides reference for other domestic new energy vehicle brand marketing strategies, so as to promote the sustainable development of the new energy vehicle industry.

\subsection{Limitations}

In the analysis of SL Company's marketing strategies, there is a lack of on-the-spot investigation on factors such as company brand image and the relationship between upstream and downstream visitors. Most of the analysis is based on theory and lacks certain data support, which may lead to deviations in conclusions from the actual situation.

\section{Acknowledgements}

Grateful acknowledgement is made to my supervisor Mr. Zhang Jihua who gave me considerable help by means of suggestions and encouragement. He helped me a lot to overcome all the difficulties. Finally, I should express my gratitude to my beloved parents who have always been supporting me.

\section{Conflicts of Interest}

The authors declare no conflicts of interest regarding the publication of this paper.

\section{References}

[1] Egbue, O. and Long, S. (2012) Barriers to Widespread Adoption of Electric Vehicles: An Analysis of Consumer Attitudes and Perceptions. Energy Policy, 48, 
717-729. https://doi.org/10.1016/j.enpol.2012.06.009

[2] Kimble, C. and Wang, H. (2013) China's New Energy Vehicles: Value and Innovation. Journal of Business Strategy, 34, 13-20.

https://www.researchgate.net/publication/256456875_China's_new_energy_vehicles _Value_and_innovation

[3] Xu, G.H. and Xu, F. (2010) Impact Factors of Purchase Decision of New Energy Automobile. China Population Resources and Environment, 20, 91-95.

http://www.wanfangdata.com.cn/details/detail.do?_type=perio\&id=zgrkzyyhj20101 $\underline{1016}$

[4] Jin, Y.H. (2012) The Marketing Strategy of New Energy Vehicle in Japan: Lessons for China. Northeast Asia Forum, 21, 105-112.

http://www.cnki.com.cn/Article/CJFDTotal-DBYL201203013.htm

[5] Xie, G.H. (2013) A Study on Marketing Strategy of Electric Vehicle of Company A. Ph.D. Thesis, Dalian University of Technology, Dalian. http://cdmd.cnki.com.cn/Article/CDMD-10141-1014154811.htm

[6] Sang, Y. and Zhang, J.M. (2014) Research on Marketing Strategy of New Energy Vehicle. China Business \& Trade, No. 31, 26-27. http://www.cnki.com.cn/Article/CJFDTotal-ZGSM201431015.htm

[7] Krupa, J.S., Rizzo, D.M., Eppstein, M.J., et al. (2014) Analysis of a Consumer Survey on Plug-In Hybrid Electric Vehicles. Transportation Research Part A Policy \& Practice, 64, 14-31.

https://www.researchgate.net/publication/261566185_Analysis_of_a_consumer_sur vey_on_plug-in_hybrid_electric_vehicles https://doi.org/10.1016/j.tra.2014.02.019

[8] Jansson, J., Nordlund, A. and Westin, K. (2017) Examining Drivers of Sustainable Consumption: The Influence of Norms and Opinion Leadership on Electric Vehicle Adoption in Sweden. Journal of Cleaner Production, 154, 176-187.

https://www.researchgate.net/publication/315705095_Examining_drivers_of_sustaina ble_consumption_The_influence_of_norms_and_opinion_leadership_on_electric_ vehicle_adoption_in_Sweden https://doi.org/10.1016/j.jclepro.2017.03.186

[9] Lieven, T., Mühlmeier, S., Henkel, S., et al. (2011) Who Will Buy Electric Cars? An Empirical Study in Germany. Transportation Research Part D Transport \& Environment, 16, 236-243.

https://www.researchgate.net/publication/49286697_Who_will_buy_electric_cars_ An_empirical_study_in_Germany https://doi.org/10.1016/j.trd.2010.12.001

[10] Liu, Z., Hao, H., Cheng, X. and Zhao, F. (2018) Critical Issues of Energy Efficient and New Energy Vehicles Development in China. Energy Policy, 115, 92-97.

https://www.researchgate.net/publication/324140687_Critical_issues_of_energy_effi cient_and_new_energy_vehicles_development_in_China https://doi.org/10.1016/j.enpol.2018.01.006

[11] Lu, M.J., Chen, S. and Lou, Y. (2013) New Energy Vehicle Development in China. International Journal of Environment \& Sustainable Development, 12, 44-59. https://www.researchgate.net/publication/264823904_New_energy_vehicle_develop ment_in_China

[12] Ma, S.-C., Fan, Y. and Feng, L.Y. (2017) An Evaluation of Government Incentives for New Energy Vehicles in China Focusing on Vehicle Purchasing Restrictions. Energy Policy, 110, 609-618. 
https://www.sciencedirect.com/science/article/pii/S0301421517304895 https://doi.org/10.1016/j.enpol.2017.07.057

[13] Wang, Z., Zhao, C., Yin, J. and Zhang, B. (2017) Purchasing Intentions of Chinese Citizens on New Energy Vehicles: How Should One Respond to Current Preferential Policy? Journal of Cleaner Production, 161, 1000-1010. https://www.sciencedirect.com/science/article/pii/S0959652617310971 https://doi.org/10.1016/j.jclepro.2017.05.154

[14] Kotler, P. (1994) Reconceptualizing Marketing: An Interview with Philipkotler. European Management Journal, 12, 353-361.

https://www.researchgate.net/publication/227416025_Reconceptualizing_marketing _An_interview_with_Philip_Kotler https://doi.org/10.1016/0263-2373(94)90021-3 